\title{
Skeletal fluorosis in Vavuniya District: an observational study
}

\author{
P B Hewavithana', W M Jayawardhane ${ }^{2}$, R Gamage ${ }^{3}$, C Goonaratna ${ }^{4}$
}

(Index words: Groundwater fluoride, skeletal fluoride toxicity, radiographic manifestations, clinical and biochemical features)

\begin{abstract}
Background The WHO recommended safe upper limit for fluoride in drinking water is $1.5 \mathrm{mg} / \mathrm{l}$. Groundwater sources in many parts of Sri Lanka often exceed this limit. The high fluoride content of groundwater and high environmental temperatures in Vavuniya District predispose to pre-skeletal fluorosis and skeletal fluorosis in adults.

Objectives To identify residents of Vavuniya District with clinical features of pre-skeletal and skeletal fluorosis; to describe their clinical, biochemical and radiographic features; to determine the fluoride content of blood and urine in individuals with established diagnoses, and of their drinking water.
\end{abstract}

Methods In 98 volunteers we detected 60 with clinical features of pre-skeletal and skeletal fluorosis. Clinical examination, biochemical and radiographic investigations were performed. Forty four with confounding factors were excluded. The balance 16 had radiographic investigation for fluoride bone disease, and assessment of clinical features for pre-skeletal fluorosis. The radiographic criteria of skeletal fluorosis were trabecular haziness, osteosclerosis, osteophytes, cortical thickening and ligamentous or muscle attachment ossification. All 16 had "spot" samples of $15 \mathrm{ml}$ of venous blood taken for biochemical tests and fluoride estimation; and $30 \mathrm{ml}$ of urine, and water from $16 \mathrm{dug}$ wells for fluoride.

Results The 16 selected (11 males) had BMI between 20.6 and $31.9 \mathrm{~kg} / \mathrm{m}^{2}$, and were between 22 and 84 years $(\bar{x}=59.9+20.4)$. They used water from domestic dug wells for drinking. All had adequate renal function. All serum and urine samples had raised fluoride levels way above the reference ranges for serum $(0.02-0.18 \mathrm{mg} / \mathrm{l})$ and urine $(0.6-2.0 \mathrm{mg} / \mathrm{l})$. The 16 water samples showed a mean fluoride content of $2.90+0.93 \mathrm{mg} / \mathrm{l}$.

Ceylon Medical Journal 2018; 63: 139-142

DOI: http://doi.org/10.4038/cmj.v63i3.8723
Interpretation In a cohort of 60 individuals in Vavuniya with symptoms suggestive of skeletal fluoride toxicity, 6 had skeletal fluorosis, 10 had pre-skeletal fluorosis, and groundwater sources had fluoride levels much higher than WHO recommended upper limit for drinking water. Residents in Vavuniya are predisposed to preskeletal and skeletal fluorosis. All 16 had been misdiagnosed as various types of arthritis.

\section{Introduction}

Fluoride toxicity is a worldwide health problem of gigantic proportions, manifesting as dental and skeletal fluorosis. For example, in India alone, about 60 million in over 200 Districts are at risk of developing skeletal fluorosis, and about 6 million are disabled by the disease. Similar results have been reported from many other countries [1].

The crucial aetiological factor for fluoride toxicity is the high fluoride content in groundwater. For development of pre-skeletal and skeletal fluorosis other determinants contribute, including duration of exposure, strenuous physical activity, and strontium in groundwater [3].

Before the onset of overt skeletal fluorosis, there is a long pre-skeletal phase during which joint pains, neck stiffness, and muscle weakness occur that mimic symptoms of familiar arthritic conditions, leading to prolonged misdiagnosis, since the overwhelming majority of doctors have never encountered a case of fluorosis. Hence serum and urine fluoride studies are never done in such cases [1,3].

Vengalcheddikulam, in Vavuniya District, has all the predisposing conditions conducive to development of fluoride toxicity: high levels of groundwater fluoride, high average daytime temperature over $35^{\circ} \mathrm{C}$, a harsh ambience with many residents engaged in farming or other labourintensive employment, requiring strenuous physical exertion and drinking copious amounts of well water.

${ }^{1}$ Department of Radiology, Faculty of Medicine, University of Peradeniya; ${ }^{2}$ Consultant Civil Engineer; ${ }^{3}$ Senior Research and Development Officer, Link Natural Products (Pvt) Ltd, ${ }^{4}$ Registrar, Ceylon Medical College Council, Colombo 8.

Correspondence: CG, e-mail: <si7np5e@gmail.com>. Received 13 September 2018 and revised version accepted 03 July 2018.

This is an open-access article distributed under the terms of the Creative Commons Attribution License, which permits unrestricted use, distribution, and reproduction in any medium, provided the original author and source are credited. 


\section{Methods}

Average daytime temperature in the Vavuniya District is about $35^{\circ} \mathrm{C}$, often exceeding $37^{\circ} \mathrm{C}$. Residents of Vengalcheddikulam (VC), a Divisional Secretary Division of Vavuniya District, were selected for our study. They obtained drinking water from dug wells, and in 82 randomly selected wells in Vengalcheddikulam, 22 (26.8\%) had between $1.6 \mathrm{mg} / \mathrm{l}$ and $4.15 \mathrm{mg} / \mathrm{l}$ fluoride in water, with a mean of $1.59 \pm$ $0.69 \mathrm{mg} / \mathrm{dl}[2]$.

Sixty long-standing residents of Vengalcheddikulam with radiographic criteria of skeletal fluorosis in axial skeleton and long bones, namely trabecular haziness, cortical thickening, osteosclerosis, osteophytes and ligamentous or muscle attachment ossification, and symptoms of pre-skeletal fluorosis, such as failure to stand unaided from squatting position or when seated on a chair, neck pain or stiffness, low back pain, and pain on flexion of either wrist, elbow, knee or hip, inability to walk unaided, were investigated. The investigations included history and examination, examination of a "spot" $15 \mathrm{ml}$ sample of blood for creatinine, urea, e-GFR, calcium, phosphate, alkaline phosphatase and fluoride; a $30 \mathrm{ml}$ "spot" sample of urine for creatinine/albumin ratio and fluoride; and groundwater samples from 16 relevant dug wells for fluoride.

Fluoride estimations were performed at the Department of Geology, Faculty of Science, University of Peradeniya by Professor Rohana Chandrajith. Other biochemical investigations were performed at the Nawaloka Metropolis Laboratories, Vavuniya. Radiographic imaging was by a qualified radiographer, advised by a Consultant Radiologist (PBH).

As symptoms and signs of patients in the pre-skeletal phase (Table 2) we used the observational data from previous studies. None of them give validated criteria for evaluation of symptoms. Four signs gleaned from these studies, namely ability to walk unaided, flexion of the spine to touch a point $10 \mathrm{~cm}$ below the patella, and standing from a chair and from a squatting position unaided, could be more objectively assessed $[1,4]$.

"Normal" values for urinary and serum fluoride given by authors vary widely. We have used urinary fluoride level between 0.6 and $2.0 \mathrm{mg} / \mathrm{l}$, and serum fluoride level between 0.02 and $0.18 \mathrm{mg} / \mathrm{l}$, as our reference values [1,4].

Although initially all 60 individuals were investigated, we excluded from the study those who had surrogate markers of renal osteodystrophy, namely, hypocalcaemia, hyperphosphataemia, ALP $>120 \mathrm{U} / 1$, and eGFR $<60 \mathrm{ml} / \mathrm{min} /$ $1.73 \mathrm{~m}^{2}$, because renal osteodystrophy would confound radiographic confirmation of bone fluorosis. Individuals in whom radiographic diagnosis confirmed other nonfluorosis bone diseases were also excluded, leaving 16 individuals conforming to the criteria of skeletal or preskeletal fluorosis.
Approval for our study was obtained from the Sri Lanka Medical Association (ERC/14 - 032).

\section{Results}

From 98 volunteers for the study we detected 60 with clinical features suggestive of pre-skeletal and skeletal fluorosis for biochemical and radiological investigation. Confounding factors were detected in 44 individuals, who were excluded from further study.

The 16 selected (11 males) had BMI between 20.6 and $31.9 \mathrm{~kg} / \mathrm{m}^{2}$, and were between 22 and 84 years $(\bar{x}=59.9$ \pm 20.4 ). They used water from domestic dug wells for drinking. All had adequate renal function. All serum and urine samples had raised fluoride levels way above the reference ranges for serum $(0.02-0.18 \mathrm{mg} / \mathrm{l})$ and urine $(0.6$ - $2.0 \mathrm{mg} / \mathrm{l})$. The 16 water samples showed a mean fluoride content of $2.90 \pm 0.93 \mathrm{mg} / \mathrm{l}$.

The mean serum calcium value of the 16 individuals was $8.77 \pm 0.30 \mathrm{mg} / \mathrm{dl}$, of phosphate $4.33 \pm 0.47 \mathrm{mg} / \mathrm{dl}$, and alkaline phosphatase $96.4 \pm 16.20 \mathrm{IU}$. Serum fluoride ranged between 0.40 and $2.14 \mathrm{mg} / \mathrm{l}(\overline{\mathrm{x}}=1.0 \pm 0.42)$, and urinary fluoride ranged from 0.88 to $3.26 \mathrm{mg} / \mathrm{l}(\overline{\mathrm{x}}=1.90 \pm 0.53)$. A summary of the biochemical investigations and demographic details of all 16 individuals is given in Table 1. The symptoms elicited and results of four tests we have performed are given in Table 2. All had neck pain or stiffness and low back pain, while pain on wrist flexion was recorded in 14, and pain on hip flexion in 13. Among the four physical signs tested, all had inability to stand unaided from squatting, 10 inability to stand from a low chair, 10 could not walk unaided, and spine flexion was limited in 9. These are the most useful diagnostic criteria for pre-skeletal and skeletal fluorosis. Their conglomeration demands testing blood and urine for fluoride and radiographic investigation [4]. All 16 despaired about the disabilities, which prevented them from sustaining livelihood. All had severe dental fluorosis according to Dean's Index Codes and Criteria [5].

Ten individuals had typical symptoms and signs of pre-skeletal fluorosis without radiographic evidence of skeletal fluorosis, while the other 6 gave a long history of pre-skeletal fluorosis and had definitive radiological evidence of skeletal fluorosis.

\section{Discussion}

Although initially 60 individuals were investigated, we excluded those with renal osteodystrophy. Also excluded were individuals in whom initial radiographic diagnosis was osteoporosis, degenerative bone disease, and chronic osteoarthritis [3].

When the radiographic diagnosis confirmed skeletal fluorosis, and the signs and symptoms were compatible, 6 were diagnosed as having skeletal fluorosis. When the radiographic diagnosis was non-contributory, and the signs and symptoms were compatible, 10 were diagnosed 
as having pre-skeletal fluorosis. All individuals had been diagnosed as having one or more of the following by numerous hospital doctors for periods varying between 4 and 15 years: osteoarthritis, cervical spondylosis, rheumatoid arthritis, gout, idiopathic skeletal hyperostosis, and ankylosing spondylitis [4].
Although the rigorous measures we have taken to exclude confounders has reduced the number that could be confidently diagnosed as pre-skeletal and skeletal fluorosis to 16 , the probability that several of the 44 individuals excluded from the study also had pre-skeletal or skeletal fluorosis remains an unresolved enigma.

Table 1. Summary of biochemical investigations in individuals with skeletal fluorosis (1 to 6) and pre-skeletal fluorosis ( 7 to 16)

\begin{tabular}{|c|c|c|c|c|c|c|c|c|c|c|c|c|}
\hline \multirow[t]{2}{*}{$\begin{array}{l}\text { Patient } \\
\text { No: }\end{array}$} & \multirow[t]{2}{*}{$\begin{array}{l}\operatorname{Sex} \\
(M / F)\end{array}$} & \multirow[t]{2}{*}{$\begin{array}{c}\text { Age } \\
\text { (years) }\end{array}$} & \multirow[t]{2}{*}{$\begin{array}{c}B . M . I \\
\left(k g / m^{2}\right)\end{array}$} & \multicolumn{3}{|c|}{ Fluoride content $(\mathrm{mg} / \mathrm{l})$} & \multicolumn{2}{|c|}{$\begin{array}{c}\text { Serum creatinine and } \\
E / G F R\end{array}$} & \multicolumn{4}{|c|}{ Serum } \\
\hline & & & & $\begin{array}{l}\text { Drinking } \\
\text { water }\end{array}$ & Serum & Urine & $\begin{array}{c}\text { Serum } \\
\text { creatinine } \\
(\mathrm{mg} / \mathrm{dl})\end{array}$ & $\begin{array}{c}E / G F R \\
(\mathrm{ml} / \mathrm{min} / \\
\left.1.73 \mathrm{~m}^{2}\right)\end{array}$ & $\begin{array}{c}\text { Urea } \\
(m g / d l)\end{array}$ & $\begin{array}{l}\text { Calcium } \\
(\mathrm{mg} / \mathrm{dl})\end{array}$ & $\begin{array}{l}\text { Phosphate } \\
\text { (mg/dl) }\end{array}$ & $\begin{array}{l}A L P \\
(U I)\end{array}$ \\
\hline 1 & M & 80 & 25.6 & 4.86 & 1.37 & 2.88 & 0.80 & 98 & 37 & 8.8 & 3.9 & 70 \\
\hline 2 & M & 80 & 22.2 & 2.48 & 0.89 & 1.46 & 0.92 & 88 & 30 & 9.2 & 4.3 & 90 \\
\hline 3 & M & 74 & 20.6 & 3.69 & 0.86 & 3.26 & 0.73 & 75 & 27 & 9.4 & 4.6 & 110 \\
\hline 4 & M & 84 & 31.9 & 2.96 & 2.14 & 1.87 & 0.76 & 101 & 19 & 8.8 & 3.9 & 80 \\
\hline 5 & M & 58 & 23.4 & 4.29 & 0.65 & 1.46 & 1.05 & 78 & 35 & 8.7 & 4.6 & 104 \\
\hline 6 & F & 32 & 25.4 & 1.85 & 0.40 & 1.20 & 1.04 & 68 & 28 & 8.3 & 4.4 & 110 \\
\hline 7 & F & 50 & 22.5 & 1.60 & 0.84 & 0.88 & 0.81 & 99 & 29 & 8.7 & 4.8 & 109 \\
\hline 8 & M & 80 & 29.0 & 1.88 & 0.71 & 2.15 & 0.90 & 79 & 24 & 8.3 & 3.7 & 114 \\
\hline 9 & M & 30 & 26.9 & 1.97 & 0.63 & 2.10 & 1.20 & 68 & 37 & 8.6 & 4.5 & 63 \\
\hline 10 & F & 42 & 23.3 & 1.63 & 0.98 & 2.03 & 0.93 & 72 & 40 & 9.1 & 4.4 & 74 \\
\hline 11 & M & 65 & 22.4 & 3.42 & 0.69 & 2.05 & 1.14 & 68 & 23 & 8.8 & 4.2 & 113 \\
\hline 12 & $\mathrm{~F}$ & 56 & 27.1 & 2.52 & 1.34 & 1.33 & 0.95 & 72 & 28 & 8.3 & 4.8 & 115 \\
\hline 13 & M & 70 & 20.6 & 1.92 & 0.66 & 1.96 & 1.07 & 93 & 23 & 9.0 & 4.2 & 103 \\
\hline 14 & M & 56 & 24.4 & 2.60 & 1.07 & 1.90 & 0.95 & 82 & 28 & 8.7 & 4.6 & 96 \\
\hline 15 & F & 64 & 23.3 & 2.70 & 1.39 & 1.92 & 0.92 & 81 & 30 & 8.7 & 3.3 & 98 \\
\hline \multirow[t]{4}{*}{16} & M & 65 & 25.2 & 2.82 & 1.30 & 1.88 & 0.98 & 82 & 29 & 8.8 & 5.3 & 94 \\
\hline & Mean & 61.63 & 24.61 & 2.70 & 1.00 & 1.90 & 0.95 & 81.50 & 29.19 & 8.76 & 4.34 & 96.44 \\
\hline & $\begin{array}{l}\text { Standard } \\
\text { deviation }\end{array}$ & 16.81 & 3.03 & 0.96 & 0.43 & 0.59 & 0.13 & 11.32 & 5.72 & 0.31 & 0.48 & 16.72 \\
\hline & SEM & 4.20 & 0.76 & 0.24 & 0.11 & 0.15 & 0.03 & 2.83 & 1.43 & 0.08 & 0.12 & 4.18 \\
\hline
\end{tabular}

Notes: BMI - Body Mass Index; ALP - Alkaline phosphatase

Table 2. Summary of symptoms and signs in individuals with skeletal fluorosis (1 to 6 ) and in pre-skeletal fluorosis (7 to 16)

\begin{tabular}{|c|c|c|c|c|c|c|c|c|c|c|c|}
\hline \multirow[b]{3}{*}{$\begin{array}{l}\text { Patient } \\
\text { No: }\end{array}$} & \multicolumn{7}{|c|}{ (i) Symptoms } & \multicolumn{4}{|c|}{ (ii) Signs } \\
\hline & \multirow[b]{2}{*}{$\begin{array}{c}\text { Neck } \\
\text { pain or } \\
\text { stiffness }\end{array}$} & \multirow[b]{2}{*}{$\begin{array}{l}\text { Low } \\
\text { back } \\
\text { pain }\end{array}$} & \multicolumn{5}{|c|}{ Pain on flexion of } & \multirow[b]{2}{*}{$\begin{array}{l}\text { Walking } \\
\text { unaided }\end{array}$} & \multirow[b]{2}{*}{$\begin{array}{c}\text { Spine } \\
\text { flexion }\end{array}$} & \multirow[b]{2}{*}{$\begin{array}{l}\text { Standing } \\
\text { from chair } \\
\text { unaided }\end{array}$} & \multirow[b]{2}{*}{$\begin{array}{c}\text { Standing from } \\
\text { squatting } \\
\text { unaided }\end{array}$} \\
\hline & & & hip & knee & ankle & elbow & wrist & & & & \\
\hline 1 & + & + & + & - & - & - & + & Yes & No & Yes & No \\
\hline 2 & + & + & + & + & + & + & + & No & No & No & No \\
\hline 3 & + & + & + & - & - & - & + & Yes & Yes & Yes & No \\
\hline 4 & + & + & + & + & + & - & + & No & No & No & No \\
\hline 5 & + & + & + & + & + & - & + & No & Yes & Yes & No \\
\hline 6 & + & + & + & - & + & - & + & Yes & No & Yes & No \\
\hline 7 & + & + & + & - & - & - & + & Yes & No & Yes & No \\
\hline 8 & + & + & + & + & - & - & + & No & Yes & No & No \\
\hline 9 & + & + & + & - & - & + & - & Yes & Yes & No & No \\
\hline 10 & + & + & - & + & + & - & + & Yes & Yes & No & No \\
\hline 11 & + & + & - & + & + & + & + & Yes & No & Yes & No \\
\hline 12 & + & + & + & - & - & + & - & Yes & No & Yes & No \\
\hline 13 & + & + & + & - & - & + & + & Yes & No & No & No \\
\hline 14 & + & + & + & + & - & - & + & No & No & No & No \\
\hline 15 & + & + & - & - & + & + & + & No & No & No & No \\
\hline 16 & + & + & + & - & + & + & + & Yes & No & Yes & No \\
\hline
\end{tabular}

Notes: (i) Symptoms (present + , absent - ). Pain on flexion of one or both sides. (ii) Signs. Possible = yes, Not possible $=$ no. (Flexion of spine is to $10 \mathrm{~cm}$ below lower border of patella by tips of extended fingers) 


\section{Conclusions}

Our study is focused on 16 individuals resident in Vengalcheddikulam, in Vavuniya District, in whom we have confirmed 10 had pre-skeletal fluorosis and 6 skeletal fluorosis. They were selected from a cohort of 60 with features suggestive of fluoride toxicity, who were further investigated after exclusion of confounders. The principal aetiological culprit is drinking water with a high level of fluoride over a long period. Both forms of fluoride toxicity had rendered the individuals disabled, and their families destitute. Among 44 individuals who were not subjected to investigation because they had radiographic and biochemical evidence of confounders, some may well have had bone fluorosis, in particular pre-skeletal fluorosis, which has no radiographic features.

The results of this study, and a previous study point to the prevalence of significant endemic fluorosis toxicity in residents of Vavuniya District, emphasising the need for a proper epidemiological study [2]. As succinctly stated by an authority on fluoride toxicity, this disabling disorder is easily preventable by providing potable water with reduced fluoride content [6]. Doctors in the Northern Province and Vavuniya District need to consider fluoride toxicity in the differential diagnosis of musculo-skeletal and arthritic disorders.

\section{Conflicts of Interest}

Authors declare that they have no conflicts of interest.

\section{References}

1. Reddy DR. Neurology of endemic skeletal fluorosis. Neurology India 2009; 57: 7-12.

2. Rajapakse PS, Jayawardhane WM, Goonaratna C, et al. High prevalence of dental fluorosis among schoolchildren in a Grama Niladhari Division in Vavuniya District. Ceylon Med J 2017; 62: 218-21.

3. Wang Y, Yin Y, L A Gilula et al Endemic fluorosis of the skeleton: Radiographic features in 127 patients. Amer J Radiol 1994; 162: 93-8.

4. Connett M. Skeletal fluorosis: the misdiagnosis problem; pre-skeletal fluorosis. Fluoride Action Network 2012; 1-12. htm 95 k. Accessed 1 Sept 2017.

5. Dean HT. The investigation of physiological effects by the epidemiological method. In fluoride and Dental Health. Ed: Moulton FR. American Association for the Advancement of Science 1942; Publication No. 191; 23-31.

6. Susheela AK. Fluorosis: an easily preventable disease through practice of interventions. Fluorosis Research and Rural Development Foundation Delhi: 2005. 